\title{
Broad Leaved Weed's Seed Bank and Flora Dynamics in Wheat as Affected by Different Herbicides
}

\author{
Safdar Ali1* ${ }^{*}$, Muhammad Amir Hanif ${ }^{1}$, Muhammad Umar ${ }^{1}$, Amir Manzoor ${ }^{1}$, Obaidullah Shafique ${ }^{1}$, Bashir \\ Ahmad Khan ${ }^{2}$ and Ijaz Ahmed ${ }^{3}$
}

${ }^{1}$ Department of Agronomy, Pir Mehr Ali Shah, Arid Agriculture University, Rawalpindi, Pakistan; ${ }^{2}$ Department of Agricultural Economics, Pir Mehr Ali Shah, Arid Agriculture University, Rawalpindi, Pakistan; ${ }^{3}$ Ecotoxicology Research Institute, National Agricultural Research Centre Islamabad, Pakistan.

Abstract | To research out an efficient chemical remedy of broad-leaved weeds in winter wheat at Pothwar Region of Pakistan, a study was performed during 2016-17 at University Research Farm Chakwal Road Rawalpindi. Four herbicides were used as once and twice application, i.e., Buctril Super (Bromoxinil 30\% with MCPA 30\% w/v), Ally Max (Metsulfuron Methyl 14.3\% w/w with Tribenuron Methyl 14.3\% w/w), Starane M (Fluroxypyre 10\% with MCPA 40\% w/w) and Clean wave (Aminopyralid 1\% with Fluroxypyre14\% w/w) at recommended doses. A weedy check and a weed free plot were also kept for comparison. Results showed that in comparison to control plot (weedy check), there was $73.41 \%$ increase in the grain yield of wheat where double spray of Ally Max was done and it was followed by 58.28\%, 54.78\%, 51.28\% and 36.59\% where double spray of clean wave, Buctril Super, Starane Mand single hand weeding were applied respectively. Similarly, there was $70.1 \%$ decrease in the seed bank of weeds where Starane $\mathrm{M}$ was sprayed twice as compared with control plot which was followed by 69.17\%, 69\%, 61.39\% and 45.18\% decrease where Ally Max twice, Buctril Super twice, clean wave twice and once hand weeding were applied respectively. So, resultantly, it is concluded that twice application of all tested herbicides gave best results for controlling flora and weeds seed bank of prevailing weeds which significantly increased the wheat yield. So, twice application of Starane M, Ally Max, Buctril Super and Clean Wave herbicides is recommended to improve the productivity of wheat along with efficient control of weed seed bank and weed flora in wheat under rain-fed conditions of Pothwar Region of Pakistan.

Received | September 30, 2019; Accepted | November 04, 2021; Published | February 16, 2022

*Correspondence | Safdar Ali, Department of Agronomy, Pir Mehr Ali Shah, Arid Agriculture University, Rawalpindi, Pakistan; Email: safdaraliarid@yahoo.com

Citation | Ali, S., M.A. Hanif, M. Umar, A. Manzoor, O. Shafique, B.A. Khan and I. Ahmed. 2022. Broad leaved weed's seed bank and flora dynamics in wheat as affected by different herbicides. Journal of Agricultural Research, 35(1): 58-69.

DOI | https://dx.doi.org/10.17582/journal.pjar/2022/35.1.58.69

Keywords | Broad leaved weeds, Seed bank, Herbicides, Wheat yield, twice

\section{Introduction}

$\mathrm{R}$ ainfed agriculture has a big role in the economy of Pakistan. Here, agriculture is mainly dependent on rainfall. This area is consisted upon $17 \%$ of total area cultivated of the Country (Adnan et al., 2009). Wheat (Triticum aestivum L.) is regarded as one of the staple foods of the large population of Pakistan. Due to this reason, farmers and researchers give su- preme importance to wheat crop in Pakistan (Jabran et al., 2011). Universally, wheat ranked second major crop as food grain in terms of area wise, production wise and consumption wise for dietary purposes after maize (Chachar et al., 2009). Wheat as sole crop is cultivated on $17 \%$ of the total land of the world and it meets $35 \%$ of total food demand. So, being the major staple food of millions of people, there is dire need to increase its production for food security (Shamsi March 2022 | Volume 35 | Issue 1 | Page 58 
et al., 2006; Hayat and Ali, 2010). It has 10.0\% share in agricultural value addition and $2.1 \%$ in Pakistan's GDP. The largest area of Pakistan's land was covered by wheat crop in past. There was 9180 thousand hectares wheat sowing area in 2014-15 while it was 9199 thousand hectares in 2013-14 in Pakistan (Anonymous, 2015).

Several approaches are used to control weeds in wheat field, such as cultural, chemical and mechanical. But the current weed control strategy is the use of herbicides round the globe (Soufizadeh et al., 2006; Mobeen et al., 2015; Qamar et al., 2015). To control weeds, chemical method is considered to be the best suitable way and herbicides prove to be a potential enhancer the productivity of crop through better control of weeds (Santos, 2009). The infestation of weeds not only resulted in less yield but also reduce the quality. It increases the harvesting, threshing and cleaning cost. Besides various agricultural practices, chemical control of weeds is proved best for enhancing wheat production and productivity (Kaur et al., 2018). But extreme and unwise use of herbicides may result in crop damage, animal and human health issues, water and soil contamination and weeds resistance against herbicides (Farooq et al., 2011). Weeds management can be taken out by both chemical and the non-chemical methods. But herbicides use has turned out to be a major tool to enhance the yield in wheat crop. Hand weeding becomes difficult because of the similarity in the physical appearance of wheat seedlings and weeds plants. However, mechanical control of weeds consumes more labor, energy, and time which in turn cause soil erosion (Monthomery, 2007). Weeds seed bank demonstrate composition, diversity, and density of weed communities. Weeds were suppressed in plots where chemical herbicides and hand weeding were applied. Chemical herbicides greatly influenced the composition of weeds in wheat crop but total density of seed decrease in both treated and untreated plots. Whereas composition of seed bank and species density were affected by herbicides (Gao et al., 2020). Weeds can also be controlled by using the extracts of plants like transgenic crop plants, breeding, mutation, sorghum stem, and other biomaterials to reduce the poisonous effect of weeds (Anwar et al., 2016; Jaffar et al., 2016). Cheema and Akhtar (2005) described that mixture of broad and narrow leaf herbicides had performed better against weeds than using separate spray of narrow and broad leaf weeds controlling herbicides in wheat. According to the thumb rule, if weed biomass and density will be less, then competition between crop and weed plants will be less. Moreover, use of herbicides and tillage practices will decrease the weeds infestation by 50 to 80\% (Chhokar and Malik, 2002). So, there is need to enhance the yield and quality of wheat crop. The profitable return of the crop depends upon the best herbicide choice, its recommended dose of application and proper time (Fayad et al., 1998). Soil seed bank composition is also influenced by using herbicides. Most research experiments have shown that the absence of herbicides has resulted into increased weed seed bank (Hyvönen and Salonen, 2002). Weed seed bank size and composition also leads to the method of farming, herbicide use, time of cultivation and crop pattern (Roberts, 1981). Considering all factors mentioned above, the aims of this research were to find out the best chemical remedy of the broad-leaved weeds to improve yield of rainfed wheat.

\section{Materials and Methods}

\section{Experimental location}

The experiment was laid out at University Research Farm Chakwal Road Rawalpindi, PMAS-Arid Agriculture University, Rawalpindi Pakistan at latitude $33.1167^{\circ} \mathrm{N}$ and longitude 73.0112 with altitude of 1715 feet $(523 \mathrm{~m})$ from sea level. The experiment was laid out during the winter season of 2016-17 using RCBD by replicating three times. Following herbicides were estimated under rain-fed conditions for controlling broad-leaved weeds.

\section{Treatments}

T1 Control (Weedy Check)

T2 Hand Weeding

T3 Buctril Super 60\% EC (Bromoxinil 30\% + MCPA 30\% w/v) applied @ $741 \mathrm{ml} \mathrm{ha}^{-1}$

T4 Ally Max 28.6\% SG (Metsulfuron Methyl (14.3\% w/w) + Tribenuron Methyl 14.3\% w/w) applied @ $34.58 \mathrm{~g} \mathrm{ha}^{-1}$

T5 Starane-M 50\% EC (Fluroxypyre 10\% + MCPA 40\% w/w) applied @741 ml ha ${ }^{-1}$

T6 Clean Wave 15\% EO (Aminopyralid 1\% + Fluroxypyre14\% w/w) applied @790.4 ml ha

T7 Buctril Super (Twice)

T8 Ally Max (Twice)

T9 Starane-M (Twice)

T10 Clean Wave (Twice)

The wheat variety AUR-10 was sown on October 25, 2016. The seed was obtained from Department 
of Plant Breeding and Genetics, PMAS-Arid Agriculture University, Rawalpindi Pakistan. The seed was used @ $120 \mathrm{~kg} / \mathrm{ha}$. The distance among the rows of crop was maintained at $22.5 \mathrm{~cm}$. The individual plot size was $4 \mathrm{~m} \times 18 \mathrm{~m}$. Replications were separated from each other by $2 \mathrm{~m}$ distance and adjacent plots were separated by $1 \mathrm{~m}$. Weed seed bank was determined by collecting the soil samples from the experimental site before and after the conductance of experiment in "W" shape, and then a composite sample was prepared from each plot. Nitrogen $(\mathrm{N})$ was applied @ $90 \mathrm{~kg} / \mathrm{ha}$ in two splits as per recommendation. First split was applied at the sowing time and $2^{\text {nd }}$ at anthesis stage. (P) Phosphorus and Potash $(\mathrm{K})$ was mixed into the soil during sowing @ 60:60 kg/ ha respectively. DAP fertilizer was applied to fulfill the requirement of Phosphorus and Urea for Nitrogen. Weather data was collected from nearby weather observatory to correlate it with the results. All the agronomic and cultural operations were carried out as per recommendations during the whole study period.

\section{Data collection}

Data were collected on composition of soil weed seed bank and soil weed seed bank density by following procedures adopted by (Kroschel, 2002; Elsaforiet al., 2011; Hussain, 2013; Ali et al., 2016; Hussain et al., 2017) and for weeds flora density, weeds dry biomass, weeds control efficiency and weeds Index by (Gupta et. al., 1998; Ali et al., 2016; Ali et al., 2017). For wheat crop data were collected on plant height, biological yield, 1000 grain weight, grain yield, and harvest Index (Beadle, 1987) by following standard protocols.

\section{Statistical analysis}

The analysis of variance (ANOVA) technique was used to analyze the data of all parameters under study. STATISTIX 8.1 Computerized software was used to analyze the data. Least significant Difference (LSD) test was used for comparing the means of treatments (Steel et al., 1997).

\section{Results and Discussion}

\section{Weather Data (Temperature and Rainfall)}

Data related to cumulative rainfall (blue bars) and daily temperature (Solid red line) during the period of experimentation are shown in Figure 1. Solid line represents that mean daily temperature of $26^{\circ} \mathrm{C}$ was recorded at the stage of germination but decrease oc- curred gradually afterwards. The average temperature during week 14 to 18 was between $12{ }^{\circ} \mathrm{C}$ to $15{ }^{\circ} \mathrm{C}$. Later on, in coming days temperature started increasing and it went up to $30^{\circ} \mathrm{C}$. Rainfall was very low during the whole cropping season and it was recorded worst dry spell of weather. Maximum rainfall of 9 $\mathrm{mm}, 5 \mathrm{~mm}$ and $4 \mathrm{~mm}$ occurred during week $25^{\text {th }}, 28^{\text {th }}$, and $30^{\text {th }}$ of the experimental period. This shows that most of rainfall occurred during reproductive stage of the crop. However, most of the weeks were observed with no rainfall during experimental period.

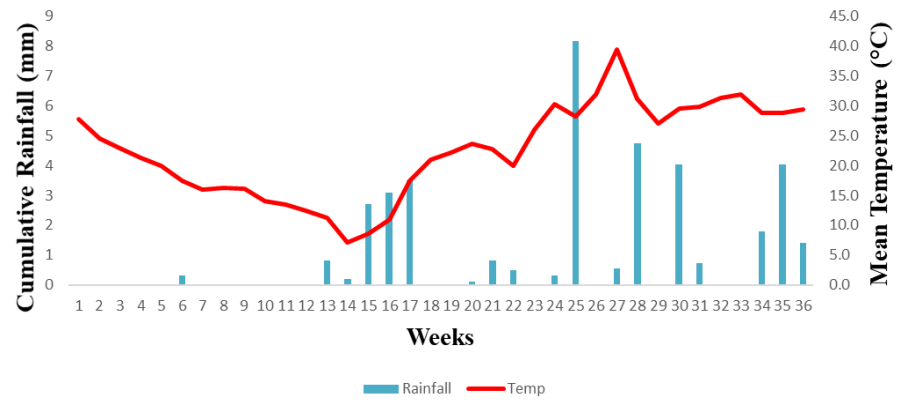

Figure 1: Temperature and rainfall data during experimental period.

Weed seed bank species composition found at experimental place

The total of 8 species of weeds belonging to 8 various families were found in soil weed seed bank under the area of experiment (University Research Farm, Chakwal Road, Rawalpindi). List of species along with English name, local name and families are showed in the Table 1.

Total weed seed bank $\left(\mathrm{m}^{-2}\right)$ before sowing and after harvesting of wheat

The soil weed seed bank is associated with total reserves of seeds that are viable to germinate in favorable conditions and it is dispersed in the soil or above the soil surface (Singh et al., 2012). The data regarding total soil weed seed bank before sowing and after harvesting of wheat is showed in Table 2. The data presented that there was no significant $(P \geq 0.05)$ difference found in total soil weed seed bank before sowing of wheat. Maximum seed number $\left(58156 \mathrm{~m}^{-2}\right)$ was obtained where hand weeding was to be performed, whereas the lowest number of seeds (36816 $\mathrm{m}^{-2}$ ) was recorded in plot where Ally max (twice) was to be applied. The non-significant difference may be due to the reason that there was not any treatment applied before the sowing of wheat and the seed was almost uniformly distributed all over the experimental field. 
Table 1: Soil weed seed bank composition found in studied area.

$\begin{array}{lllll}\text { Botanical Name } & \text { English Name } & \text { Local Name } & \text { Family } & \text { Fruit/Seed Description } \\ \text { Anagallis arvensis } & \text { Blue pimpernel } & \text { Billi booti } & \text { Primulaceae } & \text { Capsule with dark brown angular seeds } \\ \text { Chenopodium album } & \text { Lambsquarter } & \text { Bathu } & \text { Chenopodiaceae } & \text { Compond achene with black seeds } \\ \text { Melilotusindica } & \text { Yellow sweet clover } & \text { Senji } & \text { Fabaceae } & \text { Single seeded pod with orange brown seeds } \\ \text { Asphodelustenuifolius } & \text { Jungle onion } & \text { Piazi, Bhokat } & \text { Liliaceae } & \text { Capsules with black trigonous seeds } \\ \text { Convolvulus arvensis } & \text { Field bindweed } & \text { Lehli } & \text { Convolvulaceae } & \text { Capsule with brownish black seeds } \\ \text { Euphorbia helioscopia } & \text { Sun spurge } & \text { Chatridhodak } & \text { Euphorbiaceae } & \text { Capsule (Cocci) with black seed } \\ \text { Carthamusoxyacantha } & \text { Wild safflower } & \text { Pohli } & \text { Asteraceae } & \text { Achene with shining grey color seeds } \\ \text { Fumaria indica } & \text { Fumitory } & \text { Shahtra, Papra } & \text { Fumariaceae } & \text { Nut type seeds }\end{array}$

Table 2: Total soil weed seed bank $\left(\mathrm{m}^{-2}\right)$ before sowing and after harvesting of wheat.

\begin{tabular}{|c|c|c|}
\hline Treatments & $\begin{array}{l}\text { Total Soil Weed } \\
\text { Seed Bank Before } \\
\text { Sowing }\left(\mathrm{m}^{-2}\right)\end{array}$ & $\begin{array}{l}\text { Total Soil Weed } \\
\text { Seed Bank } \\
\text { After Harvest- } \\
\text { ing }\left(\mathrm{m}^{-2}\right)\end{array}$ \\
\hline Control (T1) & $38624 \mathrm{NS}$ & $62186 \mathrm{a}^{* *}$ \\
\hline Hand weeding (T2) & 58156 & $34090 \mathrm{bc}$ \\
\hline Buctril super (T3) Once & 52316 & 39022 b \\
\hline Allymax (T4) Once & 44656 & $35560 \mathrm{bc}$ \\
\hline Starane M (T5) Once & 51508 & $37224 \mathrm{~b}$ \\
\hline Clean wave (T6) Once & 38548 & $41560 \mathrm{~b}$ \\
\hline Buctril super (T7) Twice & 37870 & $18960 \mathrm{~d}$ \\
\hline Allymax (T8) Twice & 36816 & $19168 \mathrm{~d}$ \\
\hline Starane M (T9) Twice & 39806 & $18552 \mathrm{~d}$ \\
\hline Clean wave (T10) Twice & 38680 & $24008 \mathrm{~cd}$ \\
\hline LSD Value & 19316 & 11965 \\
\hline
\end{tabular}

Whereas the effect of different herbicides was found significant on total soil weed seed bank after harvesting of wheat. Maximum weeds seeds $\left(62186 \mathrm{~m}^{-2}\right)$ were recorded under control treatment plot, which was significantly $(\mathrm{P} \leq 0.05)$ greater than all other herbicidal treatments. It was followed by clean wave (once), Buctril super (once), Starane M (once) and Ally max (once) having the seed densities of (41560/ $\left.\mathrm{m}^{2}\right),\left(39022 / \mathrm{m}^{2}\right),\left(37224 / \mathrm{m}^{2}\right)$ and $\left(35560 / \mathrm{m}^{2}\right)$ respectively, but they were statistically parallel with each other. The minimum seed number $\left(18552 / \mathrm{m}^{2}\right)$ was extracted from Starane M (twice) plot which was followed by $\left(18960 / \mathrm{m}^{2}\right),\left(19168 / \mathrm{m}^{2}\right)$ and $(24008 /$ $\mathrm{m}^{2}$ ) number of seeds where Buctril super (twice), Ally max (twice) and clean wave (twice) were applied. The reason behind best control of seed bank in these treatments may be that more than one episode of herbicidal spray might have not only suppressed the single flush of weeds, but they also controlled lateral flushes along with preventing their reproduction and seeds setting. These outcomes are in line with the results of Ball (1992) who reported that herbicidal treatments significantly reduced the seed bank density of certain weeds species, while some species were resistant towards herbicides. These results are also matched with Norsworthy (2008) and Prabhu et al. (2015) who find out that some herbicides executed well against weed and prevent the formation of seed bank.

Total density $\left(\mathrm{m}^{-2}\right)$ of weeds flora before and after application of herbicides

Density of plants represents to the overall population of a community under study area. Density of weeds per unit area is the main parameter to search out the effect of treatments on growth of weeds and crop plants because weeds are the competitors of crop plants for water, nutrients, light and other resources. The data about total weeds density before application of herbicides is presented in Table 3. Chenopodium album, Anagalis arvensis, convolvulus arvensis, Euphorbia helioscopia, Cirsium arvense, Asphodelustenuifolius, Fumaria indica and Rumexdentatus were the dominant species under study area. There was no prominent $(P \geq 0.05)$ difference between the total densities of weeds in all the experimental plots before application of herbicides. These non-significant results may be due to the reason that there was not any treatment applied at this stage. The data showed that maximum weeds $\left(105.33 \mathrm{~m}^{-2}\right)$ were present in control plot and the minimum weeds $\left(77.33 \mathrm{~m}^{-2}\right)$ were found under the plot where two times application of Ally max herbicide was to be applied. The outcomes were maintained by the results of Abbas et al. (2009) who stated that there was no significant difference between the densities of weeds before application of herbicides in the experimental plots.

The statistical data revealed that there was substantial $(\mathrm{P} \leq 0.05)$ influence of herbicides on weed den- 
sity after application of herbicides. The data related to weeds density after application of herbicides is showed in Table 3. Twenty-five days after application of 1 st treatment of herbicides, it was observed that weeds were increased by $18.36 \%$ in control plot, whereas they were controlled up to $94.81 \%$ under hand weeded plots. Data revealed that best density of weeds $\left(5 / \mathrm{m}^{2}\right)$ was noted in plot where hand weeding was performed after application of $1^{\text {st }}$ episode of herbicides. Whereas the lowest density of weeds (27.33/ $\mathrm{m}^{2}$ ) was noted in plot where single application of Starane $M$ was applied which was followed by the plots where Ally max (twice to be applied) and clean wave (once) was applied having densities of (27.67/ $\left.\mathrm{m}^{2}\right)$ and $\left(30.67 / \mathrm{m}^{2}\right)$ respectively. Whereas the greater density of weeds $\left(124.67 / \mathrm{m}^{2}\right)$ was noted in Control plot where no herbicidal treatment was applied.

Table 3: Weeds density $\left(\mathrm{m}^{-2}\right)$ before and after application of herbicides.

$\begin{array}{llll}\text { Treatments } & \text { WDBFS } & \text { WDAFS } & \text { WDASS } \\ \text { Control (T1) } & 105.33 \mathrm{NS} & 124.67 \mathrm{a}^{* *} & 128.67 \mathrm{a} \\ \text { Hand weeding (T2) } & 96.33 & 5.00 \mathrm{e} & 7.00 \mathrm{f} \\ \text { Buctril super (T3) Once } & 81.67 & 65.67 \mathrm{~b} & 70.00 \mathrm{~b} \\ \text { Allymax (T4) Once } & 86.67 & 30.67 \mathrm{~d} & 33.00 \mathrm{~cd} \\ \text { Starane M (T5) Once } & 84.00 & 27.33 \mathrm{~d} & 29.33 \mathrm{de} \\ \text { Clean wave (T6) Once } & 84.00 & 48.00 \mathrm{bcd} & 50.00 \mathrm{c} \\ \text { Buctril super (T7) Twice } & 77.67 & 54.00 \mathrm{bc} & 29.00 \mathrm{de} \\ \text { Allymax (T8) Twice } & 77.33 & 27.67 \mathrm{~d} & 14.67 \mathrm{ef} \\ \text { Starane M (T9) Twice } & 81.00 & 35.00 \mathrm{~cd} & 12.33 \mathrm{ef} \\ \text { Clean wave (T10) Twice } & 88.00 & 46.67 \mathrm{bcd} & 15.00 \mathrm{ef}\end{array}$

Where, WDBFS= Weed density before first spray; WDAFS= Weed density after first spray; WDASS = Weed density after second spray

Similarly, weed densities were also significantly affected by the $2^{\text {nd }}$ application of herbicides. Weeds were further suppressed in the plots where double application of herbicides was performed having density of $\left(29 \mathrm{~m}^{-2}\right),\left(15 \mathrm{~m}^{-2}\right),\left(14.67 \mathrm{~m}^{-2}\right)$ and $\left(12.33 \mathrm{~m}^{-2}\right)$ in twice application of Buctril super, clean wave, Ally max and Starane $M$ respectively. Moreover, an increased weed density of $\left(128.67 \mathrm{~m}^{-2}\right)$ was noted in control plot after $2^{\text {nd }}$ application of herbicides. The data mentioned in Table 3 also revealed that statistically the plots of twice application of Ally max, Buctrilsuper, Starane $\mathrm{M}$ and Clean wave have non-significant differences with one another. Similar results were described by the Salahuddin et al. (2016) and Abbas et al. (2009a) who stated that there were significant results found for suppressing weed densities by using chemical herbi- cides. Khalil et al. (2013) also confirmed our findings, who stated that greater density of weeds was noted in control plot in their herbicidal wheat experiment.

Total dry weight $\left(\mathrm{g} \mathrm{m}^{-2}\right)$ of weeds before and after application of herbicides

Dry weight of weeds represents the weight of plants after the removal of all water contents in it. It represents the total weed biomass in the given area. The statistical examination of data showed that there was no significant $(\mathrm{P} \geq 0.05)$ difference in dry weight of weeds before application of herbicides. The data about the weeds dry weight is displayed in Table 4. Maximum weeds dry weight biomass $\left(73 \mathrm{~g} \mathrm{~m}^{-2}\right)$ was found in plot where single application of Starane $M$ was to be applied before application of herbicides. The lowest weeds dry weight $\left(56.33 \mathrm{~g} / \mathrm{m}^{2}\right)$ was noted in Buctril super plot which was followed by Control plot having dry weight of $\left(68.33 \mathrm{~g} / \mathrm{m}^{2}\right)$ where no treatment was to be applied. The non-significant differences in the weeds dry weight in the above-mentioned plots before herbicides application may be due to the reason that all the plots were equally infested by the weed before application of herbicides and the same kind of weeds were present in all the plots. One more reason of similarity may be due to the uniform distribution of soil weed seed bank.

The statistical analysis of data showed that there was significant $(\mathrm{P} \leq 0.05)$ impact of herbicides on dry weight of weeds after $1^{\text {st }}$ application. The data related to dry weight of weeds after spray is shown in Table 4. After application of $1^{\text {st }}$ spray, it was found that dry weight of weeds was increased up to $31.71 \%$ in control plot, whereas they were decreased up to $87.30 \%$ in hand weeded plots. The dry biomass of herbicidal treated plots was at par with each other and there was little variation found in the dry weight of weeds after application of herbicides. This little variability may be due to the reason that all herbicides performed a likely good for controlling dry weight of weeds. The best treatment against the control of weeds dry biomass was hand weeding having $\left(8.00 \mathrm{~g} / \mathrm{m}^{2}\right)$ weeds dry biomass; whereas, in single time herbicidal treated plots, minimum weeds dry weight $\left(33.33 \mathrm{~g} / \mathrm{m}^{2}\right)$ was noted in the plot where Buctril super was applied. Whereas greater weeds dry weight $\left(90 \mathrm{~g} / \mathrm{m}^{2}\right)$ was noted in plot where no weed control treatment was applied (check plot) followed by Starane M (once), Starane M (twice) and Clean Wave (once) having dry weight of (45.33g/ $\left.\mathrm{m}^{2}\right),\left(39 \mathrm{~g} / \mathrm{m}^{2}\right)$ and $\left(35.33 \mathrm{~g} / \mathrm{m}^{2}\right)$ respectively. 
Table 4: Weeds Dry Weight $\left(\mathrm{gm}^{-2}\right)$ before and after application of herbicides.

\section{TREATMENTS}

$\begin{array}{llll}\text { Control (T1) } & 68.33 \mathrm{NS} & 90.00 \mathrm{a} * & 93.33 \mathrm{a} * \\ \text { Hand weeding (T2) } & 63.00 & 8.00 \mathrm{c} & 12.00 \mathrm{c} \\ \text { Buctril super (T3) Once } & 56.33 & 33.33 \mathrm{~b} & 34.33 \mathrm{~b} \\ \text { Allymax (T4) Once } & 63.00 & 35.00 \mathrm{~b} & 31.00 \mathrm{~b} \\ \text { Starane M (T5) Once } & 73.00 & 45.33 \mathrm{~b} & 38.67 \mathrm{~b} \\ \text { Clean wave (T6) Once } & 63.33 & 35.33 \mathrm{~b} & 37.67 \mathrm{~b} \\ \text { Buctril super (T7) Twice } 63.50 & 34.00 \mathrm{~b} & 14.67 \mathrm{c} \\ \text { Allymax (T8) Twice } & 69.20 & 34.00 \mathrm{~b} & 10.67 \mathrm{c} \\ \text { Starane M (T9) Twice } & 69.23 & 39.00 \mathrm{~b} & 18.33 \mathrm{c} \\ \text { Clean wave (T10) Twice } 59.67 & 33.67 \mathrm{~b} & 20.33 \mathrm{c} \\ \text { Where, WDWBFS= Weed dry weight before first spray; WDWAFS= } \\ \text { Weed dry weight after first spray; WDWASS= Weed dry weight after } \\ \text { second spray. }\end{array}$

Table 5: Weed control efficiency (\%) and weed index as affected by different treatments.

\begin{tabular}{|c|c|c|c|}
\hline Treatments & $\begin{array}{l}\text { WCEAFS } \\
\%\end{array}$ & $\begin{array}{l}\text { WCEASS } \\
\%\end{array}$ & $\begin{array}{l}\text { WEED } \\
\text { INDEX }\end{array}$ \\
\hline Control (T1) & $0.00 c^{* *}$ & $0.00 \mathrm{~d}^{* *}$ & $0.27 \mathrm{a}^{* *}$ \\
\hline Hand weeding (T2) & $90.47 \mathrm{a}$ & $86.97 \mathrm{a}$ & $0.00 \mathrm{~cd}$ \\
\hline Buctril super (T3) Once & $60.88 \mathrm{~b}$ & $62.82 \mathrm{c}$ & $0.073 \mathrm{bc}$ \\
\hline Allymax (T4) Once & $59.85 \mathrm{~b}$ & $66.21 \mathrm{c}$ & $0.00 \mathrm{~cd}$ \\
\hline Starane M (T5) Once & $49.75 \mathrm{~b}$ & $57.61 \mathrm{c}$ & $0.173 \mathrm{ab}$ \\
\hline Clean wave (T6) Once & $59.3 \mathrm{~b}$ & $58.58 \mathrm{c}$ & $0.073 b c$ \\
\hline Buctril super (T7) Twice & $59.15 \mathrm{~b}$ & $83.83 \mathrm{ab}$ & $-0.13 \mathrm{e}$ \\
\hline Allymax (T8) Twice & $59.82 \mathrm{~b}$ & $88.40 \mathrm{a}$ & $-0.27 f$ \\
\hline Starane M (T9) Twice & $55.71 \mathrm{~b}$ & $79.85 \mathrm{ab}$ & $-0.11 \mathrm{de}$ \\
\hline Clean wave (T10) Twice & $62.02 \mathrm{~b}$ & $77.94 \mathrm{~b}$ & $-0.16 \mathrm{e}$ \\
\hline
\end{tabular}

Where, WCEAFS = Weed control efficiency after first spray; WCE$A S S=$ Weed control efficiency after second spray

Similarly, minimum dry weight of weeds $(10.67 \mathrm{~g} /$ $\left.\mathrm{m}^{2}\right)$ was found in Ally max twice plot after $2^{\text {nd }}$ spray of herbicide, which was followed by Buctril supertwice, Starane $\mathrm{M}$ twice and clean wave twice plots having $\left(14.67 \mathrm{~g} / \mathrm{m}^{2}\right),\left(18.33 \mathrm{~g} / \mathrm{m}^{2}\right)$ and $(20.33 \mathrm{~g} /$ $\mathrm{m}^{2}$ ) weeds dry weight respectively. Whereas maximum dry weight of weeds $\left(93.33 \mathrm{~g} / \mathrm{m}^{2}\right)$ was found in control plot after $2^{\text {nd }}$ application of herbicides spray. Statistically the dry weight of control plot and hand weeded plot were significantly different from one another and all other herbicidal treated plots, whereas the dry weights of all herbicidal treated plots were at par with each other and hand weeded plot after twice application of herbicides. Choudhary et al. (2016) also predicted similar results that by using different chemical herbicides weeds dry weight was significantly reduced.

Weeds control efficiency (\%) as affected by different herbicides

Efficiency means how effectively different herbicides performed to control weeds. The different herbicides showed significant effect $(p \leq 0.05)$ on weeds control efficiency. The data regarding weeds control efficiency after first spray is displayed in Table 5. The data displayed that the uppermost weed control efficiency (90.47 \%) was occurred in plot where hand weeding was performed. The minimum control efficiency of weeds $(0.00 \%)$ was measured in plot where no treatment (control) was applied. Whereas, in herbicidal treated plots the greater control efficiency of weeds $(62.02 \%)$ was found in Clean Wave twice followed by Buctril Super once and Ally Max once plot having control efficiency of, (60.88\%) (59.85\%) and (59.3\%) respectively after single spray.

Similarly, weeds were further controlled in plots where double application of herbicides was performed. The data regarding weed control efficiency after $2^{\text {nd }}$ application of herbicides is presented in Table 3. Greater control efficacy of weeds (88.40\%) was determined in Ally Max twice plot which was followed by $(86.97 \%)$ where hand weeding was performed. They were followed by $(83.83 \%),(79.85 \%)$ and $(77.94 \%)$ in plots where Buctril super, Starane $M$ and Clean wave were applied by two times. As for as the comparison of herbicidal treated plots with hand weeded plot is concerned, it was determined that double application of Ally max proved to be $1.43 \%$ more effective than hand weeded plot and Buctril Super twice performed $3.14 \%$ less efficiently than hand weeded plot. Similarly, Starane Mtwice and Clean wave twice were 7.12\% and $9.03 \%$ less efficient than hand weeded plot. The higher efficiency of hand weeding may be due to the reason that manually all kind of weeds were removed effectively by direct manual physical examination of noxious as well as invasive weeds. Pandey et al. (2001) also confirmed our findings that use of herbicides provides better control of weeds than control plot.

\section{Weeds index as affected by different herbicides}

All the herbicidal treatments depicted a significant $(\mathrm{P} \leq 0.05)$ influence on weed index. Weeds index is actually reflection of loss in yield of field crop by the reason of weed. The data related to weed index is demonstrated in Table 5. The maximum weed index (.26) 
was observed in the control plot which was followed by plots where single application of Starane M, Clean Wave and Buctril Super were applied having weed index of (.1733), (.0733) and (.0733) respectively. The lowest index weed (0.00) was noted in hand weeded plot. But similar result was found in case of Ally Max once having weed index of (0.00). Whereas, in case of double sprayed herbicidal plots, weeds index was further reduced to $(-.273),(-.156),(-.133)$ and $(-.106)$ in Ally max twice, Clean wavetwice, Buctril supertwice and Starane Mtwice, respectively. Data mentioned in Table 4 also verified that statistically plots of Hand weeded, Buctril super once, Ally maxonce, and Clean waveonce have non-significant differences with one another, moreover, Control plot and Starane M once were also statistically at par with each other. Whereas the plots of single spray and double spray were significantly different from one another.

As for as the comparison of different treatments with hand weeded plot is concerned, it was noted that $26.67 \%$ yield was decreased in the control plot through weeds as compared to hand weeded weed free plot. Whereas, (17.33\%), (7.33\%) and (7.33 \%) less yield was recorded due to weeds in the plots where single spray of Starane M, Buctril Super and Clean Wave were applied, respectively as compared to hand weeded weed free plot; whereas there was no difference found between the grain yields of hand weeded and Ally max once applied plot. Similarly, 27.30\% yield was enhanced where double spray of Ally Max was done as compared to hand weeded plot which demands the hormonal study about Ally Max and the reason behind the maximum grain yield in Ally Max due to the reason of its best control against weeds and it is also doubted that there may be a growth hormone in this herbicide which also enhanced the development and growth of crop plant which ultimately increased yield of crop. The hormonal study of this herbicide is suggested to know the actual reason behind its dual activity. Our results are similar with Shah et al. (2018) who also described that Ally max herbicide have minimum weed index because where Ally Max was applied the crop growth was significantly higher. The similar findings were described by Dadri (2003) who stated that growth and yield parameters of crop are adversely affected by the competition between crop plants and weeds which starts from the germination of crop up to harvesting of crop.
Wheat Related Parameters

Plant height $(\mathrm{cm})$ as affected by different treatments: Plant height is a combined expression of both genetic and environmental factors. The data about plant height has been shown in Table 6. It is understandable from the data that plant height was not significantly affected by different treatments. The greater height of plant $(69.58 \mathrm{~cm})$ was found in Clean wave (twice) plot and it was followed by the treatments where Buctril super (twice), Clean wave (once), Buctril super (once), Ally max (twice), Starane M (once), Hand weeding (once), Starane M (twice), and Ally max (once) was applied having plant height of $(68.26 \mathrm{~cm}),(65.30 \mathrm{~cm}),(65.30 \mathrm{~cm}),(55.24 \mathrm{~cm})$, $(50.15 \mathrm{~cm}),(48.91 \mathrm{~cm}),(48.69 \mathrm{~cm})$, and $(47.69 \mathrm{~cm})$ respectively. Whereas minimum plant height $(42.97$ $\mathrm{cm}$ ) was attained from control plot. These findings are in consonance with results of Shah et al. (1989) and Sarwar (1994) who researched out that enhancement in growth parameters is highly related with herbicidal treatments and inheritance.

1000-Kernel weight (g) as affected by different treatments: The data about weight of 1000-Kernel is displayed in Table 6. The data displayed non-significant difference among all the treatments. Maximum 1000-kernel weight (57.15 g) was recorded in plot where Buctril super (twice) was applied followed by $(54.77 \mathrm{~g}),(54.50 \mathrm{~g}),(54.30 \mathrm{~g}),(54.27 \mathrm{~g}),(53.93$ g), (53.87 g), (53.58 g), and (53.18) where Ally max (once), Strane M (twice), Buctril Super (once), Ally max (twice), Hand weeding, Starane M (once), Control and Clean wave (twice) were applied; whereas, minimum 1000-kernel weight (53.05 g) was obtained from the plot where clean wave (once) was sprayed. The non-significant results of 1000 grain weight may be due to minor effects of herbicides on weight of wheat grain under rainfed conditions (Asad et al., 2017; Hameed et al., 2019).

Grain yield $\left(\mathrm{t} \mathrm{ha}^{-1}\right)$ of wheat crop as affected by different treatments: Grain yield represents the major economical yield of a crop. The statistical data with respect to grain yield is depicted in Table 6. The data exposed that there was significant $(\mathrm{P} \leq 0.05)$ herbicides effect on grain yield of crop plants. The highest grain yield $\left(3.1425 \mathrm{t} / \mathrm{ha}^{1}\right)$ was obtained in plot in which Ally max (twice) was applied which was followed by clean wave (twice), Buctril super (twice), and Starane $\mathrm{M}$ (twice) having grain yield of (2.8683 t/ha), (2.8050 $\mathrm{t} / \mathrm{ha})$, and (2.7415 t/ha) respectively. Similarly, in case 
Table 6: Wheat parameters as affected by different treatments.

\begin{tabular}{|c|c|c|c|c|c|c|}
\hline Treatments & PH (cm) & 1000 GW (g) & $\begin{array}{l}\text { Grain Yield } \\
\left(\mathrm{tha}^{-1}\right)\end{array}$ & $\begin{array}{l}\text { Yield difference } \\
\text { with control }(\%)\end{array}$ & $\begin{array}{l}\text { Biological Yield } \\
\left(\mathrm{t} \mathrm{ha}^{-1}\right)\end{array}$ & $\begin{array}{l}\text { Harvest Index } \\
\text { (\%) }\end{array}$ \\
\hline Control (T1) & $42.97 \mathrm{NS}$ & $53.58 \mathrm{NS}$ & $1.81 \mathrm{e}^{* *}$ & 0 & $5.39 \mathrm{~d}^{* *}$ & $33.60 \mathrm{bcd}^{*}$ \\
\hline Hand weeding (T2) & 48.91 & 53.93 & $2.48 \mathrm{c}$ & +36.59 & $7.14 \mathrm{c}$ & $34.78 \mathrm{bc}$ \\
\hline Buctril super (T3) Once & 65.30 & 54.30 & $2.30 \mathrm{~cd}$ & +26.85 & $5.72 \mathrm{~d}$ & $40.67 \mathrm{a}$ \\
\hline Allymax (T4) Once & 47.69 & 54.77 & $2.48 \mathrm{c}$ & +36.42 & $7.21 \mathrm{c}$ & $34.31 \mathrm{bcd}$ \\
\hline Starane M (T5) Once & 50.15 & 53.87 & $2.04 \mathrm{de}$ & +12.61 & $5.67 \mathrm{~d}$ & $35.96 \mathrm{abc}$ \\
\hline Clean wave (T6) Once & 65.30 & 53.05 & $2.30 \mathrm{~cd}$ & +27.03 & $5.95 \mathrm{~d}$ & $38.72 \mathrm{ab}$ \\
\hline Buctril super (T7) Twice & 68.26 & 57.15 & $2.81 \mathrm{~b}$ & +54.78 & $9.02 \mathrm{~b}$ & $31.11 \mathrm{~cd}$ \\
\hline Allymax (T8) Twice & 55.24 & 54.27 & $3.14 \mathrm{a}$ & +73.41 & $10.97 \mathrm{a}$ & $28.69 \mathrm{~d}$ \\
\hline Starane M (T9) Twice & 48.69 & 54.50 & $2.74 \mathrm{~b}$ & +51.28 & $8.61 \mathrm{~b}$ & $31.92 \mathrm{~cd}$ \\
\hline Clean wave (T10) Twice & 69.58 & 53.18 & $2.87 \mathrm{~b}$ & +58.28 & $8.98 \mathrm{~b}$ & $31.94 \mathrm{~cd}$ \\
\hline
\end{tabular}

of single time sprayed herbicidal plots maximum grain yield was observed in Ally max (once) having yield of $(2.4722 \mathrm{t} / \mathrm{ha})$ which was followed by Clean wave (once), Buctril super (once) and Starane $M$ (once) having grain yields of $(2.302 \mathrm{t} / \mathrm{ha}),(2.2987 \mathrm{t} /$ ha) and $(2.0407 \mathrm{t} / \mathrm{ha})$ respectively. Hand weeded plot showed higher grain yield of $(2.4752 \mathrm{t} / \mathrm{ha})$ as compared with all the single time treated plots. But it was also noticed that hand weeded plot performed less efficient than all the herbicidal plots treated twice. The data also showed that lowest grain yield $(1.8122 \mathrm{t} / \mathrm{ha})$ was taken in control plot which was reserved as weedy check where no treatment was applied.

While comparing with control plot the data depicted that (36.59\%) grain yield was increased in hand weeded plot as compared to control plot. Whereas it was (36.42\%), (27.03\%), (26.85\%) and (12.61\%) higher in plots where Ally Max (once), Clean Wave (once), Buctril super (once) and Starane M (once) were sprayed as compared to control plot. But, in case of herbicidal plots which were treated twice showed more yield of grains than hand weeded plots. It was noted that there was $(73.41 \%)$ more yield of grains in Ally max (twice) plot as compared with control plot which was followed by clean wave (twice), Buctril Super (twice), and Starane M (twice) having more yield of grains $(58.28 \%),(54.78 \%)$, and $(51.28 \%)$ respectively. Similar findings were reported by Bibi et al. (2008); Hassan et al. (2003) and Tunio et al. (2004), who researched out that herbicide treatment had significantly affected the yield of grains.

Biological yield $\left(\mathrm{tha}^{-1}\right)$ of wheat crop as affected by different treatments: Biological yield of a crop is defined as the total biomass or dry matter accumulation of plants per unit area. Farmers are interested in both biological and grain yields as the dry biomass residue after grain separation of many crops may be used as haylage for animals. The statistical data regarding biological yield is presented in Table 6. The data displayed that there was a significant $(\mathrm{P} \leq 0.05)$ impact of herbicides on biological yield of crop. The higher biological yield (10.968 $\mathrm{t} / \mathrm{ha}$ ) was found in plot that was treated twice by Ally max herbicidal spray, which was followed by the plots where Buctril Super, Clean Wave and Starane $\mathrm{M}$ was sprayed twice having biological yields of (9.023 t/ha), (8.981 t/ha) and (8.607 $\mathrm{t} / \mathrm{ha}$ ) respectively. Whereas the lowest biological yield $(5.385 \mathrm{t} / \mathrm{ha})$ was obtained from control plot. The biological yields of $(7.211 \mathrm{t} / \mathrm{ha}),(7.136 \mathrm{t} / \mathrm{ha}),(5.947$ $\mathrm{t} / \mathrm{ha}),(5.721 \mathrm{t} / \mathrm{ha})$ and $(5.665 \mathrm{t} / \mathrm{ha})$ were recorded from the plots that were treated once with Ally max, Hand weeding, clean wave, Buctril super and Starane M Respectively. The data also confirmed that Hand weeding plot and Ally max plot (once)were statistically non-significant from one another. Whereas, Control plot, Buctril super, Starane M and Clean wave that were treated once were also non-significantly different from each other. As for as the comparison of herbicide treatments with Hand weeded plot is concerned, it was noted that Hand weeded plot performed best among all the single time treated plots, but herbicidal plots that were treated twice proved better than hand weeding. Because manual pulling and hoeing of weeds from the area cleared equally all kind of grassy and broad-leaved weeds, but it may have also caused some damage to crop plants. The similar findings were discovered by Ashrafi et al. (2009) who confirmed that herbicides significantly increased biological yield as compared with control Plot. 
Harvesting index of wheat crop as affected by different treatments: Harvesting index is the ratio of grain yield verses total biomass produced by the wheat crop. The statistical data with reference to harvest index is showed in Table 6. The data depicted that there was significant $(\mathrm{P} \leq 0.05)$ effect of herbicide treatments on harvesting index of wheat crop. The data revealed that maximum harvest index (40.67) was obtained in the plot where Buctril Super (once) was sprayed which was followed by clean wave (once), Starane M (once), Hand weeding and Ally max (once) plot having the harvesting index of (38.72), (35.96), (34.77) and (34.30) respectively. But in case of plots, which were treated twice with herbicides, showed lower harvesting index than other plots. It was noted that Ally max (twice) showed harvesting index of (28.69) which was followed by Buctril super (twice), Starane M (twice) and Clean Wave (twice) having harvest index of (31.11), (31.92) and (31.94) respectively. The harvesting index of (33.60) was found in Control plot where no treatment was applied. It is obvious from the data that harvesting index of control treatment was higher than twice application of herbicides but lower than single application of herbicides. The reason behind higher harvest index under single application and lower harvest index found under twice application of herbicidal plots may be that wheat crop growth was higher under twice application and ultimately the crop plants gained higher plant biomass/biological yields compared to grain biomass/grain yield which reduced the harvest index under twice application of herbicides. Lower harvest index of control plot was also reported by Hossain et al. (2009) who, applied herbicides only once. These findings were also in agreement with Hassan et al. (2001) who researched that higher harvesting index was noted in herbicidal treated plots and minimum harvesting index was noted in control plot.

\section{Conclusions and Recommendations}

Double spray of Ally Max increased the grain yield by $73.41 \%$, whereas double spray ofClean wave, Buctril Super, Starane Mand once hand weeding produced $58.28 \%, 54.78 \%, 51.28 \%$ and $36.59 \%$ higher grain yield than control respectively. Similarly, double spray of Starane M reduced $70.1 \%$ broad leaved weeds seed bank as compared to control, whereas double spray of Ally Max, Buctril Super, Clean wave and once hand weeding reduced soil weed seed bank by $69.17 \%$, 69\%, 61.39\% and $45.18 \%$ respectively. Thus, this re- search concluded that twice application of herbicides performed best in rain-fed areas to control the seed bank and flora of broad-leaved weeds of winter wheat which ultimately increased the yield of wheat crop significantly. So, resultantly, keeping in view the types of prevailing weeds, twice application of all studied herbicides in this research is recommended to improve the productivity of wheat along with efficient control of weed flora and weeds seed bank in wheat under rainfed conditions of Pothwar Region of Pakistan.

\section{Acknowledgments}

The corresponding author is highly thankful to the Higher Education Commission of Pakistan for funding this research through Project number 21-1082/ SRGP/R\&D/HEC/2016

\section{Novelty Statement}

Mostly farmers of Pothwar Region of Pakistan are doing subsistence kind of farming due to infertile and erodible soils, small land holdings, unpredicted pattern of rainfalls and lack of investment. They are not controlling weeds regularly in wheat due to lack of awareness. Through this study we have proved that they can increase $73.41 \%$ yield and income by double spray of herbicides in wheat

\section{Author's Contribution}

Safdar Ali: Conceived the idea and executed the research.

Muhammad Amir Hanif: Wrote the article and helped in execution of research.

Muhammad Umar: Helped in writing of introduction.

Amir Manzoor: Helped in writing of materials and methods.

Obaidullah Shafique: Wrote abstract and helped in execution of research.

Bashir Ahmad Khan: Wrote conclusion and did statistical analysis.

Ijaz Ahmed: Provided technical input at every step and reviewed the article.

\section{Conflict of interest}

The authors have declared no conflict of interest. 
References

Abbas, G., Ali, M.A., Abbas, Z., Aslam, M. and Akram, M. 2009. Impact of different herbicides on broadleaf weeds and yield of wheat. Pak. J. Weed Sci. Res., 15(1): 1-10.

Abbas, S.H., Saleem, M., Maqsood, M., Mujahid, M.Y. and Saleem, R. 2009. Weed density and grain yield of wheat as affected by spatial arrangements and weeding techniques under rainfed conditions of Pothowar. Pak. J. Agric. Sci., 46(4): 242-247.

Adnan, S., Mahmood, R. and Khan, A.H. 2009. Water balance conditions in rainfed areas of Potohar and Balochistan plateau during 193108. World Appl. Sci. J., 7(2): 162-169.

Ali, S., Malik, M.A., Ansar, M., Qadir, G. and Qureshi, R. 2016. Seed Bank Density and Weed Flora Dynamics of Convolvulus arvensis as Affected by Different Tillage Systems in Rainfed Wheat (Triticum aestivum).Int.J.Agric. Biol., 18: 231-237. https://doi.org/10.17957/ IJAB/15.0031

Ali. S., M.N. Tahir, G.A. Shah, M.A. Khan and S. Mahmood. 2017. Dynamics of seed bank and weed flora in rain-fed wheat as affected by different tillage systems. Pak. J. Agric. Sci., 54(4): 907-917. https://doi.org/10.21162/ PAKJAS/17.5023

Anonymous. (2014-15). Pakistan Economic Survey. Govt. of Pakistan, Ministry of Finance, Economic Advisor's Wing, Islamabad. Chapter-2 Agriculture, 3-4.

Anwar, M.W., Ali, Q., Ali, M.Z., Jaffar, M.A.B., Khan, T.M. and Nasir, I.A. 2016. Genetic association among morphological and plant growth related traits of Medicago polymorpha. NY Sci. J., 9(4): 27-31. https:// doi.org/10.1007/978-3-319-29118-5_4

Asad, M., S. Ali, M.R. Ansar, I. Ahmad, M. Suhaib and M.K. Abuzar. 2017. Weed and wheat dynamics preceding different herbicides. Pak. J. Agric. Res., 30(4): 346-355. https://doi. org/10.17582/journal.pjar/2017/30.4.346.355

Ashrafi, X., Rahnavard, Y.A. and Sedigheh, S. 2009. Analogy potential effects of planting methods and tank mixed herbicides on wheat yield and weed population. J. Agric. Technol., 5(2): 391403.

Ball, D.A. 1992. Weed seedbank response to tillage, herbicides, and crop rotation sequence. Weed
Sci., 40(4): 654-659. https://doi.org/10.1017/

S0043174500058264

Beadle, C.L. 1987. Techniques in Bioproductivity and photosynthesis. Chapter 2. Plant Growth Anal. pp. 20-24.

Bibi, S., Marwat, K.B., Hassan, G. and Khan, N.M. 2008. Effect of herbicides and wheat population on control of weeds in wheat. Pak. J. Weed Sci. Res., 14(3-4): 111-119.

Chachar, Q.I., Chachar, M.A. and Chachar, S.D. 2009. Studies on integrated weed management in wheat (Triticum aestivum L.). J. Agric. Technol., 5(2): 405-412.

Cheema, M.S. and Akhtar, M. 2005. Efficacy of different post emergence herbicides and their application methods in controlling weeds in wheat. Pak. J. Weed Sci. Res., 11(1/2): 23-29.

Chhokar, R.S. and Malik, R.K. 2002. Isoproturonresistant littleseedcanarygrass (Phalaris minor) and its response to alternate herbicides. Weed Technol., 16(1): 116-123. https://doi. org/10.1614/0890-037X(2002)016[0116:IRL CPM]2.0.CO;2

Choudhary, D., Singh, P.K., Chopra, N.K. and Rana, S.C. 2016. Effect of herbicides and herbicide mixtures on weeds in wheat. Indian J. Agric. Res., 50(2): 107-112. https://doi. org/10.18805/ijare.v50i2.9587

Dadari, S.A. 2003. Evaluation of herbicides in cowpea/cotton mixture in Northern Guinea Savannah. J. Sustain. Agric. Enviorn., 5: 153159.

Elsafori, A.K., Guma, A.N. and El Nour, M.A. 2011. Soil seed banks of a rangeland area White Nile State, Sudan. J. Horticult. Forest., 3(6): 178-185.

Farooq, G.B., Fiaz, K.B., Marwat and Khan, M. 2011. Effect of planting methods and tank mixed with herbicides for controlling grassy and broad leaf weeds and their effect on weed. Fakhre-Sarhad. Pak. J. Weed Sci. Res., 9(1-2): 1-11.

Fayad, T.B., Sabry, S.R.S. and Aboul, E.S.H. 1998. Effect of herbicides on weed density, wheat grain yield, and yield components. In Conf. Weed Biol., Control. Stuttgart Hohenheim, Germany, pp. 14-16.

Gao, P., Zhang, Z., Shen, J., Mao, Y., Wei, S., Wei, J. and Qiang, S. 2020. Weed seed bank dynamics responses to long-term chemical control in a rice-wheat cropping system. Pest 
Manage. Sci., 76(6): 1993-2003. https://doi. org/10.1002/ps.5731

Gupta, O.P. 1998. Weed Management: Principles and Practices. Agro Botanica, Bikaner, India.

Hameed, Z., M.A. Malik., S. Ali, M. Ansar, F. Shaheen, I. Ahmad and K. Kalim. 2019. Comparative efficiency of different postemergence herbicides for controlling broadleaved weeds in rain-fed wheat. Pak. J. Agric. Res., 32(1): 78-86. https://doi. org/10.17582/journal.pjar/2019/32.1.78.86

Hassan, G., Faiz, B. and Marwat, K.B. 2003. Effects of planting methods and tank mixed herbicides on controllinggrassy and broadleaf weeds and their effect on wheat cv. Fakhr-e-Sarhad. Pak.J. Weed Sci. Res., 9(1/2): 1-11.

Hayat, R. and Ali, S. 2010. Contribution of water use efficiency of summer legumes to produce rainfed wheat. Int. J. Agric. Biol., 12: 655-660.

Hussain, A. 2013. Weed identification Manual. Directorate of Agronomy, Ayub Agricultural Research Institute, Faisalabad.

Hussain, M., Ali, S., Tahir, M.N., Shah, G.A., Ahmad, I., Sarwar, M.A., and Latif, S. 2017. A comparative study of soil weed seed bank determination in pothwar region by using different methodologies. Pak. J. Agric. Res., 30(4): 310-315. https://doi.org/10.17582/ journal.pjar/2017/30.4.310.315

Hussain, N., Khan, M.B., Khan, B., Tariq, M. and Hanif, S. 2003. Spectrum of activity of different herbicides on wheat. Intl. J. Agric. Biol., 5(2):166-168.

Hussain, Z., Marwat, K.B., Munsif, F., Samad, A., and Ali, K. 2013. Evaluation of various herbicides and their combinations for weed control in wheat crop. Pak.J. Bot., 45(1): 55-59.

Hossain, M., Malik, M.A., Farooq, M., Khan, M.B., Akram, M. and Saleem, M.F. 2009. Exogenous glycinebetaine and salicylic acid application improves water relations, allometry and quality of hybrid sunflower under water deficit conditions. J. Agron. Crop Sci., 195(2): 98-109.

Hyvönen, T. and Salonen, J. 2002. Weed species diversity and community composition in cropping practices at two intensity levels-a sixyear experiment. Plant Ecol., 159(1): 73-81. https://doi.org/10.1023/A:1015580722191

Jaffar, M.A.B., Ali, Q., Ali, M.Z., Anwar, M.W., Khan, F.A. and Nasir, I.A. 2016.
Genetic variability among different traits of

Convolvulous arvensis. Nat. Sci., 14(5): 62-65.

Kaur, R., Shivay, Y.S., Singh, G., Virk, H.K., Sen, S. and Rajni. 2018. Increasing area under pulses and soil quality enhancement in pulsebased cropping systems-Retrospect and prospects. Indian J. Agric. Sci., 88(1): 10-21.

Khalil, M.F., Hassan, G., Ahmad, G., Anwar, S. and Khan, S. 2013. Comparative efficacy of herbicides on yield and yield Components of wheat. ARPN J. Agric. Biol. Sci., 8(1): 76-80.

Kroschel, J. (Ed.). 2002. A technical manual for parasitic weed research and extension. Kulwer Academic Publishers, Dordrecht, The Netherlands. https://doi.org/10.1007/978-94010-0005-5

Mobeen, A., Qurban, A., Sadia, A., Harrem, K., Ali, A., Arfan, A. and Tayyab, H. 2015. Estimation of Correlation among various morphological traits of Coronopusdidymus, Euphorbia helioscopia, Cyperusdifformis and Aristida adscensionis. NY Sci. J., 8(4): 47-51.

Montgomery, D.R. 2007. Soil erosion and agricultural sustainability. Proceed. Nat. Acad. Sci., 104(33): 13268-13272.

Norsworthy, J.K. 2008. Effect of tillage intensity and herbicide programs on changes in weed species density and composition in the southeastern coastal plains of the United States. Crop Prot., 27(2): 151-160. https://doi. org/10.1016/j.cropro.2007.04.019

Pandey,J., Singh, R.and Verma,A.K.2001.Influence of herbicides on weed management in potato. Acta Agronomica Hungarica, 49: 183-187. https://doi.org/10.1556/AAgr.49.2001.2.9

Prabhu, G., Srinivasan, R., Kantwa, S.R., Palsaniya, D.R. and Chaudhary, M. 2015. Weed seed bank studies in the field of Fodder Cowpea [Vigna unguiculata (L.)]. Int. J. Appl. Pure Sci. Agric., 1: 83-87.

Qamar, Z., Aaliya, K., Nasir, I.A., Farooq, A.M., Tabassum, B., Qurban, A. and Husnain, T. 2015. An overview of genetic transformation of glyphosate resistant gene in Zea mays. Nat. Sci., 13(3): 80-90.

Roberts, H.A. and Neilson, J.E. 1981. Changes in the soil seed bank of four long-term crop/ herbicide experiments. J. Appl. Ecol., 18(2): 661-668. https://doi.org/10.2307/2402425

Salahuddin, Akram, M. and Alluddin. 2016.Impact of various herbicides on dicot weeds in wheat 
(Triticum aestivum L.). Curr. Sci. Perspect., 2(3): 45-51.

Santos, B.M. 2009. Drip-applied metam potassium and herbicides as methyl bromide alternatives for Cyperus control in tomato. Crop Prot., 28(1): 68-71. https://doi.org/10.1016/j. cropro.2008.08.013

Sarwar, M. and Skirvin, R.M. 1994. 889 PB 469 In vitro selection for dwarfism in apple. Hort. Sci., 29(5): 561c-561.

Shah, A.M., S. Ali, I. Ahmad, G. Wazir, O. Shafique, M.A. Hanif, B.A. Khan and S. Zareen. 2018. Weeds population studies andwheat productivity as influenced by different sowing techniques and herbicides. Pak. J. Agric. Res., 32(1): 87-94. https://doi.org/10.17582/journal. pjar/2019/32.1.87.94

Shamsi, I.H., Jilani, G., Marwat, K.B., Mahmood, Q., Khalid S. and Hayat, Y. 2006. Response of
Poaceous Weeds in Wheat to Post-Emergence Weed management practices. Caspian J. Envron. Sci., 4: (1) 9-16.

Singh, A., Kaur, R., Kang, J.S. and Singh, G. 2012. Weed dynamics in rice-wheat cropping system. Glob. J. Agric. Health Sci., 1: 7-16.

Soufizadeh, S., Zand, E., Baghestani, M.A., Kashani, F.B., Nezamabadi, N. and Sheibany, K. 2006. Integrated weed management in saffron (Crocus sativus). II Int. Symp. Saffron Biol. Technol., 739: 133-137. https://doi. org/10.17660/ActaHortic.2007.739.17

Steel, R.G., Torrie, J.H. and Dickey, D.A. 1997. Principles and procedures of statistics: A biological approach. McGraw-Hill, New York.

Tunio, S.D., S.N. Kaka, A.D. Jarwar and M.R. Wagan. 2004. Effect of integrated weed management practices on wheat yield. Pak. J. Agric. Engg. Vet. Sci., 20(1): 5-10. 